\title{
Pre-incubation of ruminal inocula to assess in vitro gas production and digestibility
}

\author{
Juan Manuel Cantet ${ }^{1,2^{*}(D)}$ Darío Colombatto ${ }^{1,2}$ Marisa Wawrzkiewicz ${ }^{1}$ Gustavo Jaurena $^{1}$ (D)
}

${ }^{1}$ Departamento de Producción Animal, Facultad de Agronomía, Universidad de Buenos Aires (FAUBA), Ciudad Autónoma de Buenos Aires, Argentina. ${ }^{2}$ Consejo Nacional de Investigaciones Científicas y Técnicas (CONICET), C1425FQB, Ciudad Autónoma de Buenos Aires, Argentina. E-mail: juanmcantet@gmail.com. "Corresponding author.

\begin{abstract}
In vitro gas production techniques represent a valuable tool to describe the kinetics of ruminal degradation of food. However the ruminal liquor used as a microbial inoculum has been a great source of variation and error. A standardization of this factor should contribute to assure the independence of food fermentation parameters from those of the inocula. In this research it was hypothesized that a controlled pre-incubation treatment of ruminal liquor could contribute to stabilize and homogenize the undigested residues of blanks and as a consequence, of the production of residual cumulative gas production (CGP). A pre-incubation (i.e. previous real incubation) of rumen inocula was developed with a simple substrate similar to the diet offered to donors at 1\% w/v for 0, 1, 2 and $4 \mathrm{~h}$ (Control, Prei-1, Prei-2 and Prei-4 treatments respectively). Once the pre-incubation hours were completed, they were incubated with contrasting substrates and without substrate (i.e. blanks) in order to evaluate the CGP, in vitro digestibility of the DM and fermentation products. Although, the fermentative activity of the pre-incubated inoculums worked satisfactorily in the in vitro system, contrary to what was speculated, residues of the pre-incubation increased the variability and heterogeneity of variances among blanks. Consequently, it was concluded that the pre-incubations did not work to generate more homogeneous and less variable ruminal liquor for the in vitro gas production system.
\end{abstract}

Key words: Inoculum preparation, rumen fluid, blanks variability.

Pré-incubação de inóculo ruminal para avaliação da produção de gases e digestibilidade in vitro

RESUMO: Técnicas de produção de gás in vitro representam uma ferramenta valiosa para descrever a cinética de degradação ruminal dos alimentos. No entanto, o líquido ruminal utilizado como inóculo microbiano tem sido uma grande fonte de variação e erro. A padronização deste fator deve contribuir para garantir a independência dos parâmetros de fermentação dos alimentos a partir dos inóculos. Neste trabalho, hipotetizou-se que um tratamento controlado de pré-incubação do líquido ruminal poderia contribuir para estabilizar e homogeneizar os resíduos não digeridos dos brancos e, como conseqüência, da produção de produção cumulativa de gás residual (CGP). Uma pré-incubação (ou seja, incubação real prévia) dos inóculos do rúmen foi desenvolvida com um substrato simples semelhante à dieta oferecida aos doadores a 1\% p/v por 0, 1, 2 e 4 h (Controle, Prei-1, Pré- 2 e Prei-4 tratamentos respectivamente). Uma vez completadas as horas de pré-incubação, elas foram incubadas com substratos contrastantes e sem substrato (ou seja, brancos) para avaliar o CGP, a digestibilidade in vitro da MS e os produtos de fermentação. Embora a atividade fermentativa dos inóculos pré-incubados tenha funcionado satisfatoriamente no sistema in vitro, ao contrário do que foi especulado, os resíduos da pré-incubação aumentaram a variabilidade e heterogeneidade das variâncias entre os brancos. Consequentemente, concluiu-se que as pré-incubações não funcionaram para gerar um líquido ruminal mais homogêneo e menos variável para o sistema de produção de gás in vitro.

Palavras-chave: preparação do inóculo, fluido ruminal, variabilidade dos brancos.

In vitro gas production techniques (ivGPT, MENKE \& STEINGASS, 1988; THEODOROU et al., 1994) are widely employed to offer a repetitive, economical and easily applicable laboratory technique to estimate in vitro dry matter digestibility (ivDMD), based on the correspondence between dry matter degradability and cumulative gas production (CGP, MOULD et al., 2005). While these techniques are used and accepted worldwide, the inoculum has been considered the main source of variation (RYMER et al., 2005; WILLIAMS, 2000; YANG, 2017).

The husbandry conditions of experimental animals (RYMER et al., 2005) and their diet (BOGUHN et al., 2013) are parameters which require more control if we look for standard conditions in the system. Thus, the ideal rumen fluid should provide a diverse (i.e. capable of supplying representatives of the different microorganisms groups), healthy and active microbial starter capable of developing and imitating the rumen digestion process. Consequently, and in order to get comparable results (i.e. among laboratories and runs), blank bottles are run simultaneously (i.e. fermentation bottles with rumen fluid and buffer without substrate). Even though blanks have been analyzed in the past as correctors of CGP (ARAUJO 
et al., 2011; CARRO et al., 2005), there is scarce information about the control of variability and the fermentative capacity thereof.

Throughout this paper it was hypothesized that a pre-incubation treatment (Pre-i) could contribute to the stabilization of the non-digested residues (responsible of the variability of blank bottles); and consequently, to the residual CGP. The objective of this study was to obtain a ruminal inoculum capable of performing in vitro incubations that could minimize the variability of blanks and improve reproducibility.

Rumen fluid (ca. liquid: solid fraction, 50: 50) from two male adult sheep with permanent rumen cannulas, fed on a standard diet (ca. alfalfa hay: corn grain, 70: 30), was collected in the morning (i.e. 12 $\mathrm{h}$ fasting). Pre-incubations were conducted into two liters dark plastic bottles which had a perforated cap to allow continuous $\mathrm{CO}_{2}$ influx. The inocula were preincubated with carbonate-bicarbonate buffer $(1: 10$ ratio, MENKE \& STEINGASS, 1988) and a substrate (alfalfa hay: corn grain, 70:30, similar to the donors diet at $1 \% \mathrm{w} / \mathrm{v}$, dried and milled $=1 \mathrm{~mm}$ ) for $0,1,2$ and 4 hours respectively (i.e. Control, Prei-1, Prei-2 and Prei-4), so that each treatment initial incubation time was different. Immediately before the incubation of bottles, pre-incubated inocula were strained through four layers of cheesecloth into a flask with $\mathrm{O}_{2}$ free headspace and an aliquot was assessed for $\mathrm{pH}\left(\mathrm{Hanna}^{\circledR}\right.$ HI-9025) and ammonia $\mathrm{N}$ concentration $\left(\mathrm{N}-\mathrm{NH}_{3}\right.$, Uremia Kit, Wiener $\left.{ }^{\circledR}\right)$. Immediately after filtered, 4 $\mathrm{ml}$ of ruminal inocula were added with $38 \mathrm{ml}$ of the buffer (1:10 ratio) to each bottle (100 $\mathrm{ml}$ of capacity), and were kept in a thermostatic bath at $39^{\circ} \mathrm{C}$ for $24 \mathrm{~h}$. Each treatment was incubated in triplicate with two substrates $(0.250 \pm 0.025 \mathrm{~g} \mathrm{DM}$, dried and milled= $1 \mathrm{~mm})$, a commercial dairy concentrate (CON) and alfalfa hay (Organic matter $[\mathrm{OM}]=925$ and 872, neutral detergent fiber with $\alpha$-amylase $\left[\mathrm{aNDF}_{\mathrm{OM}}\right]=$ 340 and 596, acid detergent fiber $\left[\mathrm{ADF}_{\mathrm{OM}}\right]=124$ and 388 , lignin $=32$ and 113 and crude protein $[\mathrm{CP}]=185$ and $193 \mathrm{~g} / 100 \mathrm{~g} \mathrm{DM}$, for CON and Hay respectively) and they were run together with five blanks per treatment (analytical replicates). In vitro CGP was performed according to THEODOROU et al. (1994). Pressure (T443A, Bailey and Mackey Ltd, UK) was measured at 1, 2, 4, 6, 8, 12, 16 and $24 \mathrm{~h}$. The gross CGP (GCGP) was corrected by the CGP of blanks to generate net CGP (NCGP).

After $24 \mathrm{~h}, \mathrm{pH}$ was measured in each bottle, aliquots were taken to assess volatile fatty acids (VFA; stabilized with $25 \%$ orthophosphoric acid; 1:5, acid: sample) and $\mathrm{N}_{-} \mathrm{NH}_{3}$ (stabilized with $0.02 \mathrm{~N}$ sulfuric acid, 1:1, acid: sample) and the fermentation residues were filtered through fiber filter bags $\left(\mathrm{ANKOM}^{\circledR}\right.$ \#F57, ANKOM technology, NY, USA) to calculate the ivDMD after being treated with neutral detergent solution according to VAN SOEST et al. (1966) as follows,

$\mathrm{ivDMD}=\left(100-\mathrm{aNDF}_{\mathrm{OM}}\right.$ residue $) \times 100 /(\mathrm{DM}$ incubated)

Samples were prepared by drying $\left(65^{\circ} \mathrm{C}\right.$, $48 \mathrm{~h}$ ) and milling ( $1 \mathrm{~mm}$; Willey mill), then they were analyzed for DM $\left(105^{\circ} \mathrm{C}\right.$ during $\left.4 \mathrm{~h}\right)$, ash (AOAC, 1990, \#942.05), CP (total $\mathrm{N} \times 6.25$, by Kjeldahl, AOAC, 1990, \#976.05) with a Pro-Nitro ${ }^{\circledR}$ (Selecta J.P., Barcelona, Spain) and ether extract (Soxhlet apparatus with petroleum ether, AOAC, 1990, \#920.39), $\mathrm{aNDF}_{\mathrm{OM}}$ and $\mathrm{ADF}_{\mathrm{OM}}$ were reported ashfree according to VAN SOEST et al. (1991) with an ANKOM $^{\circledR}$ equipment (Model 220, ANKOM $^{\mathrm{TM}}$, NY, USA). Lignin content was obtained from sulfuric acid (AOAC, 1990, \#973.18D). The VFA were analyzed with a gas chromatograph (Nukol capillary column [30 m $\times 0.32 \mathrm{~mm}$ i.d. $\times 0.25 \mu \mathrm{m}$ film thickness]; Perkin Elmer - Elite FFAP; Part. N9316354. Carrier: Hydrogen. Column flow: $2.4 \mathrm{~mL} / \mathrm{min}$. Standar: volatile acid mix Supelco [Cat. No. 46975-U]).

A Complete Block Design (block $\equiv$ run) with a factorial arrangement (i.e. four treatments and two substrates) was used and represented by the following model:

$\mathrm{Y}_{\mathrm{ijkl}}=\alpha_{\mathrm{i}}+\beta_{\mathrm{j}}+\gamma_{\mathrm{k}}+(\alpha \times \gamma)_{\mathrm{ik}}+\varepsilon_{\mathrm{ijkl}}$,

Where, $\mathrm{Y}_{\mathrm{ijk}}$ is the measured parameter of the ijk treatment, $\alpha_{i}$ the effect of substrates $(i=2)$, $\beta_{\mathrm{J}}$ the effect of block or run $(\mathrm{j}=3), \gamma_{\mathrm{k}}$ the effect of treatment $(\mathrm{k}=4),(\alpha \times \gamma)_{\mathrm{ik}}$ the interaction of substrate and treatment and $\varepsilon_{\mathrm{ijkl}}$ is the residual error term.

The CGP was adjusted to a non-linear model (i.e. $\left.\mathrm{CGP}=\mathrm{A}+\mathrm{B} \times\left(1-\mathrm{e}^{(-\mathrm{c} \times \mathrm{t})}\right)\right)$ using the NLIN procedure of SAS (2002). Data of VFA, $\mathrm{N}_{-} \mathrm{NH}_{3}$ and $\mathrm{pH}$ as well as CGP fitting parameters driven from different Pre-i were compared against the Control through Dunnett's test, through Proc Mixed of SAS (2002), with Kenward-Roger approximation. Differences were declared significant when $\mathrm{P}<0.05$. Regression analysis was performed using the REG procedure (SAS, 2002) and correlations between the values with and without blank corrections through the Proc CORR (SAS, 2002). Differences among treatments variances in blanks were tested by Bartlett's test.

It is desirable that the CGP of blanks constitute a small proportion of the total gas produced 
by substrates incubations, with low variability among replicates. In this study, it was reported that par A (fraction rapidly disappeared) of fermentation kinetic model in blanks was not different from zero for any treatment $(\mathrm{SEM}=0.127$; Table 1$)$ and that replicates contributed to $33 \%$ of their total variability. However, PAYNE et al. (2002) reported that the collection of rumen fluid with 4 or $8 \mathrm{~h}$ fasting reduced CGP variability between runs compared with an inoculum extracted with a $12 \mathrm{~h}$ fasting (i.e. Control inoculum used here), generating greater reproducibility. The Pre-incubated inocula tested here were incubated at 1,2 and $4 \mathrm{~h}$ after providing substrate to the bacterial population similar to the inocula obtained post-intake, but in a more controlled environment than the rumen itself. Moreover, initial inoculum characteristics were similar for pre-incubated rumen fluids of blanks $(\mathrm{pH}=$
7.0, $\mathrm{SEM}=0.13 ; \mathrm{P}>0.05 ; \mathrm{N}-\mathrm{NH}_{3}=38 \mathrm{mg} / \mathrm{L} ; \mathrm{SEM}=$ $3.1 ; \mathrm{P}>0.05)$.

The CGP of blanks during the first hour of incubation $\left(\mathrm{CGP}_{\mathrm{t1}}\right)$ did not show differences among treatments $(\mathrm{P}>0.05)$, being the total variation mostly described by the period and it was also shown that $\mathrm{CGP}_{\mathrm{t} 1}$ differed from 0 (Control and Prei-1, $\mathrm{P}<0.09$; Prei-2 and Prei-4, $\mathrm{P}<0.05)$. Parameter A of the model accounted for less than $3 \%$ to the total gas produced in $24 \mathrm{~h}(\mathrm{~A}+\mathrm{B})$, but both model predictions as well as actual measurements increased sharply within the first hour of fermentation reaching to 19 to $37 \%$; consequently, the rate of CGP (Par c) was high to accommodate to this fact. This fast increment in CGP should be as result of residual gas dissolved in the original inoculum (CORNOU et al., 2013) and fermentable leftovers escaping the filtering

Table 1 - Cumulative gas production and volatile fatty acids contents of rumen fluid pre-incubation treatments of blanks for $0,1,2$ and $4 \mathrm{~h}$ (Control, Prei-1, Prei-2 and Prei-4 respectively).

\begin{tabular}{|c|c|c|c|c|c|c|c|c|c|}
\hline \multirow[t]{2}{*}{ Variable $^{\mathrm{a}}$} & \multicolumn{4}{|c|}{ Treatments } & \multirow[t]{2}{*}{$\mathrm{SEM}^{\mathrm{b}}$} & \multirow[t]{2}{*}{$\operatorname{Sign}^{\mathrm{c}}$} & \multicolumn{2}{|c|}{$\begin{array}{l}\text { Distribution of } \\
\text { variability }^{\mathrm{d}}(\%)\end{array}$} & \multirow[t]{2}{*}{$\begin{array}{c}\text { Heterogeneity of } \\
\text { variance }^{\mathrm{e}}\end{array}$} \\
\hline & $\begin{array}{c}\text { Control } \\
n=3\end{array}$ & $\begin{array}{c}\text { Prei-1 } \\
n=3\end{array}$ & $\begin{array}{c}\text { Prei-2 } \\
n=3\end{array}$ & $\begin{array}{c}\text { Prei-4 } \\
n=3\end{array}$ & & & Run & Res & \\
\hline \multicolumn{10}{|c|}{--- } \\
\hline $\mathrm{A}(\mathrm{ml})$ & 0.19 & 0.05 & 0.02 & 0.33 & 0.127 & ns & 67 & 33 & ${ }^{*}$ \\
\hline $\mathrm{B}(\mathrm{ml})$ & $7.3 \mathrm{a}$ & $16.2 b$ & $14.2 \mathrm{a}$ & $11.9 \mathrm{a}$ & 2.37 & ${ }^{*}$ & 53 & 47 & ns \\
\hline $\mathrm{c}\left(\mathrm{h}^{-1}\right)$ & 0.44 & 0.21 & 0.24 & 0.28 & 0.054 & ns & 73 & 27 & $*$ \\
\hline \multicolumn{10}{|c|}{ 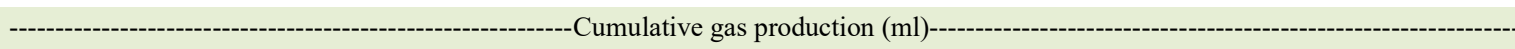 } \\
\hline $\mathrm{t} 1$ & 2.9 & 2.7 & 3.4 & 3.7 & 0.88 & ns & 79 & 21 & $n^{*} \quad$ \\
\hline $\mathrm{t} 1-\mathrm{t} 24$ & $4.7 \mathrm{a}$ & $12.7 \mathrm{~b}$ & $10.7 \mathrm{~b}$ & $8.6 \mathrm{a}$ & 1.53 & * & 56 & 44 & ns \\
\hline $\mathrm{t} 24$ & $7.9 \mathrm{a}$ & $15.9 \mathrm{~b}$ & $14.0 \mathrm{~b}$ & $12.3 \mathrm{a}$ & 2.22 & * & 68 & 32 & ns \\
\hline \multicolumn{10}{|c|}{ - Volatile fatty acids (VFA, mmol/l) - } \\
\hline Totals & $27.0 \mathrm{a}$ & $43.6 \mathrm{~b}$ & $52.8 \mathrm{~b}$ & $52.2 \mathrm{~b}$ & 3.10 & ${ }^{*}$ & 90 & 10 & ${ }^{*}$ \\
\hline Acetic acid & $14.9 \mathrm{a}$ & $30.0 \mathrm{~b}$ & $27.8 \mathrm{~b}$ & $30.3 b$ & 2.52 & * & 79 & 21 & ns \\
\hline Propionic acid & $5.3 \mathrm{a}$ & $12.9 \mathrm{~b}$ & $13.3 \mathrm{~b}$ & $13.6 \mathrm{~b}$ & 1.67 & * & 98 & 2 & $*$ \\
\hline Butiric acid & 3.1 & 3.5 & 3.7 & 4.8 & 1.19 & ns & 57 & 43 & * \\
\hline Valeric acid & 3.6 & 3.6 & 3.6 & 3.6 & 3.01 & ns & 99 & 1 & * \\
\hline Acetic/Propionic & 3.2 & 2.4 & 2.5 & 2.3 & 0.54 & ns & 97 & 3 & * \\
\hline $\begin{array}{l}\mathrm{Ac}+\mathrm{Pr} / \mathrm{VFA} \\
\text { totals }(\%)\end{array}$ & 78 & 87 & 85 & 84 & 8.9 & $\mathrm{~ns}$ & 97 & 3 & $*$ \\
\hline
\end{tabular}

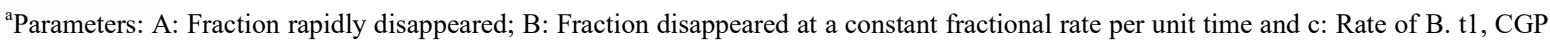
to hour 1; t1-t24, CGP from hour 1 to hour 24; t24, CGP at 24 h. Acetic/Propionic, Rate between acetic and propionic acids; Ac+Pr/AGV totals, Proportion of acetic acid + propionic acid in total VFA concentration. ${ }^{\mathrm{b}}$ Standard error of the mean, $\mathrm{n}=3$, correspond to 3 independent runs. ${ }^{\mathrm{c}}$ Sign, Significance; ns, non significative; ${ }^{*}, \mathrm{P}<0.05$. Comparisons according to Dunnett (Control vs Prei-1, Prei-2 and Prei-4), different letters in the same line indicated $\mathrm{P}<0.05 .{ }^{\mathrm{d}}$ Run (i.e. variation among inocula); Res, Residual of the error (i.e. variation among replicates/bottle). ${ }^{\mathrm{e}}$ Assessed by Bartlett's test; ns, not significant $(\mathrm{P}>0.05) ;{ }^{*}, \mathrm{P}<0.05$. 
process. Considering the small magnitude of these contributions, it is not surprising the heterogeneity of variances observed among treatments (Table 1). Furthermore, GIERUS et al. (2008) reported that the effect of runs increased the variability in CGP of corrected blanks, which would suggest that the preincubation of inocula does not imply a uniform $\mathrm{CGP}_{\mathrm{t} 1}$ or Par A. The CGP after the first hour of incubation $\left(\mathrm{CGP}_{\mathrm{tl}-124}\right)$ and during the complete incubation $\left(\mathrm{CGP}_{\mathrm{t} 24}\right)$ were significantly $(\mathrm{P}<0.05)$ affected by Prei1 and Prei-2. Conversely, Par B (fraction disappeared at a constant fractional rate) showed an increment in the Prei-1, which could be explained by the increased microbial activity in pre-incubated treatments as a result of the extra substrate offered (LUTAKOME et al., 2017) even though the inocula maintained the fermentative characteristics and normal buffer capacity (ARAUJO et al., 2011). Likewise, for Par $\mathrm{B}$ a linear correspondence was reported with $\mathrm{CGP}_{\mathrm{t} 24}$ $\left(\mathrm{CGPt}_{24}(\mathrm{ml})=0.98(\mathrm{SE}=0.018) \times \mathrm{B}+0.27(\mathrm{SE}=\right.$ $\left.0.243), r^{2}=0.98\right)$.

In order to generate trustable data there must exist a balance between inocula microbial activity and their reproducibility among different laboratories and times (CORNOU et al., 2013), in this sense CGP of blanks must be significantly different from zero (as an expresion of microbial activity), and should present low variability among replicates within incubation batchs while representing a low proportion of CGP of the assessed samples. In this sense, our preincubation treatments almost doubled Control CGP at $24 \mathrm{~h}(15.9,14.0,12.3$ and $7.9, \mathrm{ml}$, for Prei-1, Prei-2, Prei-4 and Control) reflecting a media environment more favorable for microbial fermentation and reaching close to the minimum CGP for blanks recommended by NAGADI et al. (1999; i.e. $15.5 \mathrm{ml}$ in $24 \mathrm{~h}$ ).

The increase of VFA concentration on Pre-i in ca. 94\% $(\mathrm{P}<0.05$; Table 1) could been explained by acetic and propionic acids $(84 \%$ of total VFA in all treatments; $\mathrm{P}>0.05)$. This increase was observed due to the incorporation of additional substrate in Pre-i inocula. Even though acetic + propionic acids increased in Pre-i, no statistical differences were reported in the proportion of these acids in totals VFA, as well as in acetic/propionic ratio, valeric and butyric acids concentration ( $\mathrm{P}>0.05$; Table 1). In general (except for butyric acid), replicates contributed scarcely to total variation (i.e. 1 to $21 \%$ of distribution of variability). For all VFA (except for acetic acid) variance treatments were heterogeneous. These changes in VFA concentrations could induce a change in the $\mathrm{N}_{-} \mathrm{NH}_{3}$ concentration; however, no differences were reported (Great mean $=51.3 \mathrm{mg} / \mathrm{L}$; $\mathrm{SEM}=8.02 ; \mathrm{P}>0.05)$ possibly due to the fact that the dependence of this parameter on the diet protein level is much stronger (OUDA \& NSAHLAI, 2009). Conversely, $\mathrm{pH}$ near to neutral (Great mean $=7.3$; $\mathrm{SEM}=0.07 ; \mathrm{P}>0.05$ ) could maintain the viability of the microbial population (BUENO et al., 2005).

Analysis of NCGP (after correction with blank) parameters showed differences associated with the treatments on Par B (Prei-1 was 99\% higher than Control, $\mathrm{P}<0.05$; Table 2), but no differences were reported in Par A and Par c $(\mathrm{P}>0.05)$. The variability of Par A was largely explained by internal variability (62\% of total), and for Par B, there was large variability among bottles (95\% of total variation) despite large differences of Prei-2 and Prei-4 compared to Control. Replicates accounted for the highest percentage of variability of kinetic parameters.

These results are contrary to what GETACHEW et al. (2002) found in an interlaboratory assay or those reported by KEIM et al. (2017) in different in vitro systems wherein most variation came from laboratory source or in vitro system assay.

When analyzing the ivDMD, there were differences between substrates $(\mathrm{P}<0.05$, Table 2) but the Pre-i did not produce changes $(\mathrm{P}>0.05)$, and $\mathrm{N}-\mathrm{NH}_{3}$ concentration was similar and coherent with literature (LORENZ et al., 2011). The fermentation parameters of CON (758 g/ $/ \mathrm{kg}$ of ivDMD and 347 $\mathrm{ml} / \mathrm{g}$ DM of NCGP) were similar to a fermentation of a concentrate (mixture of cereal grains, dried beet pulp and soybean hulls) reported by GIERUS et al. (2008; i.e. $720 \mathrm{~g} / \mathrm{kg}$ of ivDMD and $328 \mathrm{ml} / \mathrm{g}$ DM of NCGP assessed by Hohenheim gas test).

Volatile fatty acids profiles did not have differences among treatments $(\mathrm{P}>0.05$, Table 2$)$. However, assessment of substrates effects on VFA production showed a noticeable increment $(\mathrm{P}<0.05)$ for $\mathrm{CON}$ regarding Hay. Moreover, Hay showed an increased acetic/propionic ratio (Hay= 2.8; $\mathrm{CON}=2.1 ; \mathrm{P}<0.05)$. Likewise, GETACHEW et al. (2005) tested eight different commercial dairy concentrates and even though VFA profiles were lower than those reported here, the relationship between acetic/propionic was similar (i.e. 2.4 and 2.1 , for the 8 rations and $\mathrm{CON}$, respectively). This similar behavior of Pre-i and Control on fermentation kinetics, ivDMD and ruminal environment were coherent with the characteristics of a normal inoculum (DIJKSTRA et al., 2005). 
Table 2 - Parameters of the kinetic of net cumulative gas production (with blanks correction), in vitro dry matter digestibility (ivDMD), $\mathrm{pH}$, ammonia-N $\left(\mathrm{N}-\mathrm{NH}_{3}\right)$ and volatile fatty acids of rumen fluid pre-incubated for $0,1,2$ and $4 \mathrm{~h}$ (Control, Prei-1, Prei-2 and Prei-4, respectively) with 2 substrates incubated for $24 \mathrm{~h}$.

\begin{tabular}{|c|c|c|c|c|c|c|c|c|c|c|c|c|}
\hline \multirow[t]{2}{*}{ Parameters $^{\mathrm{a}}$} & \multicolumn{4}{|c|}{ Treatments } & \multirow[t]{2}{*}{$\mathrm{SEM}^{\mathrm{b}}$} & \multirow[t]{2}{*}{$\operatorname{Sign}^{\mathrm{c}}$} & \multicolumn{2}{|c|}{ Substrate $^{\mathrm{d}}$} & \multirow[t]{2}{*}{ SEM } & \multirow[t]{2}{*}{ Sign } & \multicolumn{2}{|c|}{$\begin{array}{l}\text { Distribution of } \\
\text { variability }^{\mathrm{e}}(\%)\end{array}$} \\
\hline & $\begin{array}{c}\text { Control } \\
n=6\end{array}$ & $\begin{array}{c}\text { Prei-1 } \\
n=6\end{array}$ & $\begin{array}{c}\text { Prei-2 } \\
n=6\end{array}$ & $\begin{array}{c}\text { Prei-4 } \\
n=6\end{array}$ & & & $\begin{array}{l}\mathrm{CON} \\
\mathrm{n}=12\end{array}$ & $\begin{array}{l}\text { Hay } \\
n=12\end{array}$ & & & Run & Res \\
\hline \multicolumn{13}{|c|}{ - } \\
\hline A (ml) & -4.7 & -6.9 & -4.7 & -2.4 & 1.00 & ns & -6.9 & -2.4 & 0.66 & ${ }^{* * *}$ & 38 & 62 \\
\hline B (ml) & $205 a$ & $408 b$ & $286 a$ & $313 a$ & 27.5 & * & 347 & 259 & 17.8 & ** & 5 & 95 \\
\hline$c\left(h^{-1}\right)$ & 0.03 & 0.02 & 0.03 & 0.02 & 0.006 & ns & 0.03 & 0.01 & 0.004 & ** & 41 & 59 \\
\hline \multicolumn{13}{|c|}{ 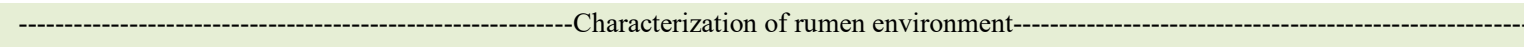 } \\
\hline $\begin{array}{l}\text { ivDMD } \quad(g / k g \\
\text { DM) }\end{array}$ & 662 & 632 & 643 & 652 & 6.7 & ns & 758 & 536 & 104.9 & $* * *$ & 36 & 64 \\
\hline $\mathrm{pH}$ & $7.2 \mathrm{a}$ & $7.1 \mathrm{~b}$ & $7.1 \mathrm{~b}$ & $7.1 \mathrm{~b}$ & 0.04 & *** & 7.0 & 7.2 & 0.03 & $* * *$ & 66 & 34 \\
\hline N-NH3 (mg/l) & 50.9 & 53.9 & 43.8 & 45.8 & 5.69 & ns & 46.7 & 50.5 & 3.56 & ns & 13 & 87 \\
\hline \multicolumn{13}{|c|}{ - } \\
\hline Totals & 29.8 & 24.9 & 31.9 & 31.2 & 3.92 & ns & 39.7 & 19.2 & 2.41 & $* * *$ & 41 & 59 \\
\hline Acetic acid & 17.7 & 14.4 & 17.9 & 18.9 & 3.84 & ns & 21.1 & 13.4 & 3.08 & $* * *$ & 58 & 42 \\
\hline Propionic acid & 7.9 & 6.8 & 8.5 & 8.3 & 0.89 & ns & 11.6 & 4.1 & 0.62 & $* * *$ & 30 & 70 \\
\hline Butyric acid & 3.9 & 2.5 & 3.2 & 2.8 & 0.48 & ns & $4.9 \mathrm{a}$ & 1.2 & 0.33 & *** & 59 & 41 \\
\hline
\end{tabular}

${ }^{a}$ Parameters: A: Fraction rapidly disappeared; B: Fraction disappeared at a constant fractional rate per unit time and c: Rate of B. ${ }^{\mathrm{b}}$ Standard error of the mean. ${ }^{\mathrm{c}}$ Sign; Significance; ns, not significant $(\mathrm{P}>0.05) ;{ }^{*}, \mathrm{P}<0.05 ;{ }^{* *}, \mathrm{P}<0.01 ;{ }^{* * *}, \mathrm{P}<0.001$. Comparisons according to Dunnett (Control vs PreI-1, Prei-2 and Prei-4), different letters in the same line indicated $\mathrm{P}<0.05$ for treatments or substrates. ${ }^{\mathrm{d}} \mathrm{CON}$, commercial concentrate for dairy cows; Hay, alfalfa hay. ${ }^{\mathrm{e}}$ Run (i.e. variation among inocula); Res, Residual of the error (i.e. variation among replicates/bottle).

Analysis of correlation between NCGP (after correction with blank) and GCGP (without correction) parameters obtained from a non-linear modeling CGP of full database showed that only Par A $(r=0.83)$ and $B(r=0.52)$ were significant $(\mathrm{P}<0.001)$. For each treatment, the analysis showed a significant relationship between the Par A of corrected and uncorrected models (r, 0.71, 0.68, 0.64 and 0.93 for Control, Prei-1, Prei-2 y Prei-4 respectively; $\mathrm{P}<0.05$ ). On the contrary, Par B and Par c did not show a similar behavior $(\mathrm{P}>0.05)$ which indicated that blanks had a significant effect on the estimation of these parameters and only in the first hours of fermentation, blanks correction would not affect the NCGP of substrates (JUDD \& KOHN, 2018).
Conversely, the Pre-i generated a greater variability and heterogeneity of variances, visible in a poor correlation between the corrected and uncorrected CGP. The largest proportion of total gas produced by blanks is released in the early hours of incubation (ARAUJO et al., 2011), and it is unusual to find a minor influence of the correction in Par A in contrast to Par B and Par c (Figure 1).

Although the objective of this research was to generate a more stable and robust inoculum, it was reported that Pre-i generated greater variability due to a poor correlation between corrected and uncorrected CGP. Furthermore, alterations in the production and fermentation rate possibly produced due to the extra substrate offered in the pre-incubations could have generated a greater and less controlled microbial 


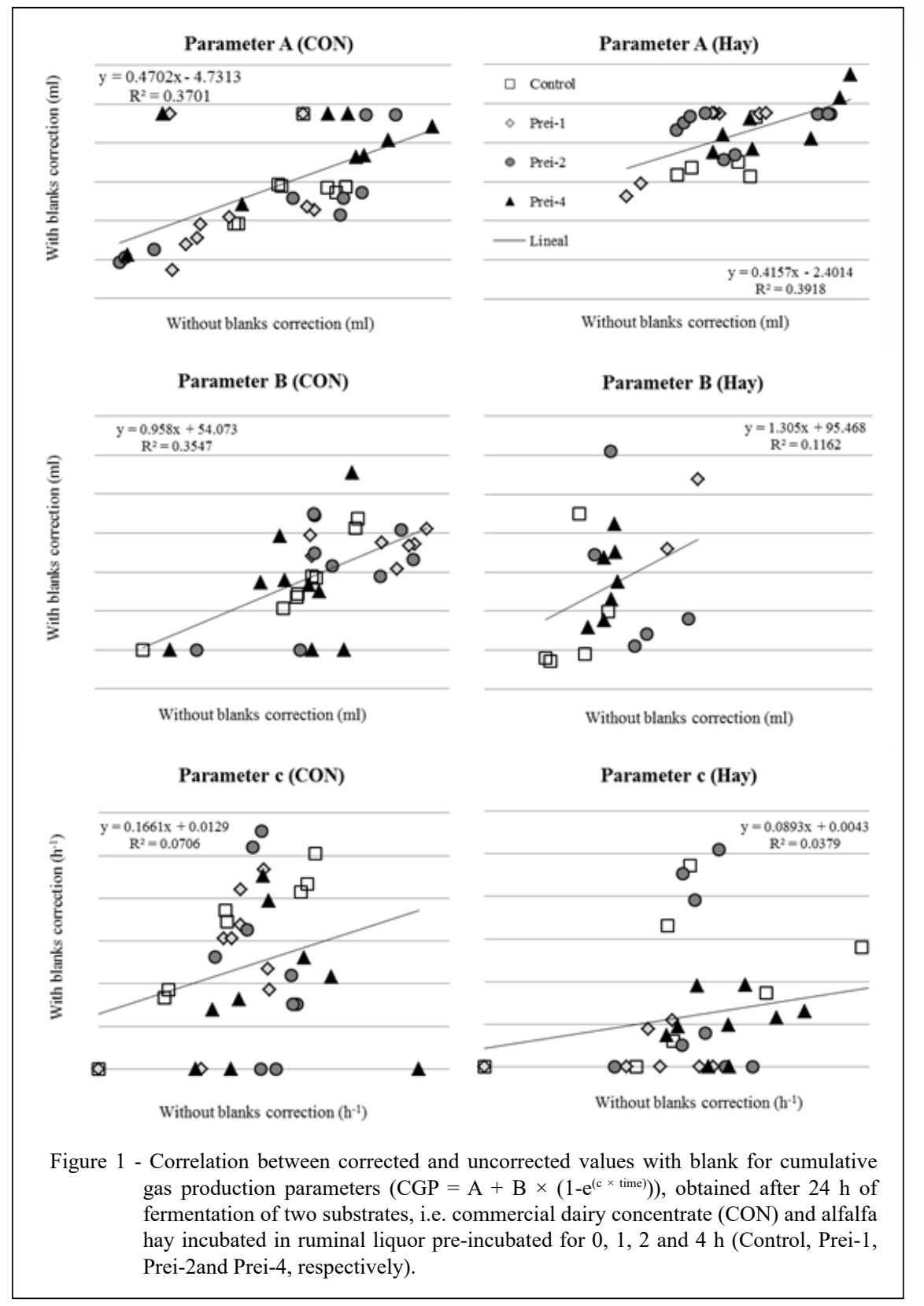

activity. The authors believe that further studies are necessary to assess the possibility of extending the pre-incubatory times, but always considering the control of production of fermentation products.

\section{ACKNOWLEDGEMENTS}

The authors acknowledge the University of Buenos Aires for the financial support (UBACyT 569-11, entitled "Metanogénesis y eficiencia de digestión ruminal de forrajeras templadas y megatérmicas"). The doctoral grant for J.M. Cantet was provided by the University of Buenos Aires and by the National Scientific and Technical Research Council (CONICET, Argentina).

\section{BIOETHICS AND BIOSSECURITY COMMITTEE APPROVAL}

We authors of the article CR-2019-0486 entitled "Preincubation of ruminal inocula to assess in vitro gas production and digestibility" declared, for all due purposes, the project that gave rise to the present data of the same has not been submitted for evaluation to the Ethics Committee of the Faculty of Agronomy, University of Buenos Aires, Argentina, but we are aware of the content of the Brazilian resolutions of the National Council for Control of Animal Experimentation - CONCEA. Thus, the authors assume full responsibility for the presented data and are available for possible questions, should they be required by the competent authorities. 


\section{DECLARATION OF CONFLICT OF INTERESTS}

We have no conflict of interest to declare. The founding sponsors had no role in the design of the study; in the analyses, or interpretation of data; in the writing of the manuscript, and in the decision to publish the results.

\section{AUTHORS' CONTRIBUTIONS}

The authors contributed equally to the manuscript.

\section{REFERENCES}

AOAC. Association of Official Analytical Chemists. Official Methods of Analysis. 16th Edit ed. Arlington, VA, USA. 1990.

ARAUJO, R. C. et al. Use of blanks to determine in vitro net gas and methane production when using rumen fermentation modifiers. Animal Feed Science and Technology, 2011. v.166167, n.11, p.155-162. Available from: $<$ http://linkinghub.elsevier. com/retrieve/pii/S037 7840111001283>. Accessed: Jan. 28, 2014. doi: 10.1016/j.anifeedsci.2011.04.009.

BOGUHN, J.; ZUBER, T.; RODEHUTSCORD, M. Effect of donor animals and their diet on in vitro nutrient degradation and microbial protein synthesis using grass and corn silages. Journal of Animal Physiology and Animal Nutrition, 2013. v.97, n.3, p.547-57. Available from: <http://www.ncbi.nlm.nih.gov/ pubmed/22487195>. Accessed: Jan. 21, 2014. doi: 10.1111/j.14390396.2012 .01295 .

BUENO, I. C. S. et al. Influence of inoculum source in a gas production method. Animal Feed Science and Technology, 2005. v.123-124, p.95-105. Available from: < http://linkinghub.elsevier. com/retrieve/pii/S0377840105001975>. Accessed: Jan. 6, 2014. doi: 10.1016/j.anifeedsci.2005.05.003.

CARRO, M. D.; RANILLA, M. J.; TEJIDO, M. L. Using an in vitro gas production technique to examine feed additives: Effects of correcting values for different blanks. Animal Feed Science and Technology, 2005. v.123-124, p. 173-184. Available from: $<$ http://linkinghub. elsevier.com/retrieve/pii/S0377840105001914> Accessed: Jan. 13, 2014. doi: 10.1016/ j.anifeedsci.2005.04.045.

CORNOU, C. et al. A ring test of a wireless in vitro gas production system. Animal Production Science, 2013. v.53, n.6, p.585-592. Available from: <https://www.publish. csiro.au/an/an12091> Accessed: Nov. 26, 2018. doi: 10.1071/AN12091.

DIJKSTRA, J. et al. Application of the gas production technique to feed evaluation systems for ruminants. Animal Feed Science and Technology, 2005. v.123-124, p.561-578. Available from: $<$ http:// linkinghub.elsevier.com/retrieve/pii/S0377840105001835>. Accessed: Jan. 6, 2014. doi: 10.1016/j.anifeedsci.2005.04.048

GETACHEW, G. et al. Laboratory variation of $24 \mathrm{~h}$ in vitro gas production and estimated metabolizable energy values of ruminant feeds. Animal Feed Science and Technology, 2002. v.102, n.14, p.169-180. Available from: <http://linkinghub.elsevier.com/ retrieve/pii/ S0377840102002122>. Accessed: Jan. 12, 2014. doi: 10.1016/S0377-8401(02)00212-2.

GETACHEW, G. et al. Methane production from commercial dairy rations estimated using an in vitro gas technique. Animal
Feed Science and Technology, 2005. v.123-124, p.391-402. Available from: <http://linkinghub.elsevier.com/retrieve/pii/ S0377840105001720>. Accessed: Jan. 6, 2014. doi: 10.1016/j. anifeedsci.2005.04.056.

GIERUS, M. et al. Comparison of gas accumulation profiles of several feeds using manual or automated gas production methods. Animal Feed Science and Technology, 2008. v.147, n.4, p.310 325. Available from: <https://www.sciencedirect.com/science/ article/pii/ S0377840108000369>. Accessed: Nov. 26, 2018. doi: 10.1016/j.anifeedsci.2008.02.001.

JUDD, L. M.; KOHN, R. A. Test of conditions that affect in vitro production of volatile fatty acids and gases. Journal of Animal Science, 2018. v.96, n. April, p.694-704. Available from: $<$ https://academic.oup.com/jas/advance-article/doi/10.1093/ jas/skx082/4828034>. Accessed: Mar. 16, 2019. doi: 10.1093/ jas/skx082.

KEIM, J. P. et al. Comparison of rumen in vitro fermentation of temperate pastures using different batch culture systems. Animal Production Science, 2017. v.57, n.4, p.690-696. Available from: $<$ https://www.publish.csiro.au/AN/AN15190>. Accessed: Nov. 25, 2018. doi: 10.1071/AN15190.

LORENZ, M. M. et al. Recycling of microbial N and estimation of protein degradation by in vitro gas production. Animal Feed Science and Technology, 2011. v.170, n.1-2, p.111-116. Available from: <http://linkinghub.elsevier.com/retrieve/pii/ S0377840111003257>. Accessed: Jan. 28, 2014. doi: 10.1016/j. anifeedsci.2011.07.012

LUTAKOME, P. et al. Rumen liquor from slaughtered cattle as inoculum for feed evaluation. Animal Nutrition, 2017. v.3, n.3, p.300-308. Available from: <http://dx.doi.org/10.1016/ j.aninu.2017.06.010>. Accessed: Mar. 17, 2019. doi: 10.1016/j. aninu.2017.06.010

MENKE, K. H.; STEINGASS, H. Estimation of the energetic feed value obtained from chemical analysis and in vitro gas production using rumen fluid. Animal Research and Development, 1988 v. 8, p. $7-55$.

MOULD, F. L.; KLIEM, K. E.; MORGAN, R. Alternative methodologies - stretching the in vitro box. Animal Feed Science and Technology, 2005. v.123-124, p.501-515. Available from: <http://linkinghub.elsevier.com/retrieve/pii/ S0377840105001665>. Accessed: Jan. 6, 2014. doi: 10.1016/j. anifeedsci.2005.04.023

NAGADI, S.; HERRERO, M.; JESSOP, N. S. Effect of frequency of ovine ruminal sampling on microbial activity and substrate fermentation. In: Proceeding of British Society of Animal Science, 1999, p.154. Penicuik, UK. (abstract). Available from: $<$ https://www. cambridge.org/core/journals/proceedings-of-thebritish-society-of-animal-science/article/ effect-of-frequencyof-ovine-ruminal-sampling-on-microbial-activity-and-substratefermentation/B8DA649D1786767C2EEA852630E11214>. Accessed: Jan. 12, 2014. doi.org/10.1017/S1752756200003094.

OUDA, J. O.; NSAHLAI, I. V. Relevance and potential use of in vitro gas production measurements to evaluate varying ratios of roughages and protein sources for ruminants. Journal of Applied Animal Research, 2009. v.35, n.1, p.9-16. Available from: <https:// www.tandfonline.com/doi/pdf/10.1080/09712119.2009.9706975> Accessed: Jan. 12, 2014. doi: 10.1080/ 09712119.2009.9706975.

Ciência Rural, v.50, n.8, 2020. 
PAYNE, J. S. et al. The affect of rumen fluid collection time on its fermentative capacity and the stability of rumen conditions in sheep fed a constant diet. In: Proceedings of British Society of Animal Production, 2002. p.165. (abstract). Available from: $<$ https://www. cambridge.org/core/journals/proceedings-of-the-british-society-ofanimal-science/article/ affect-of-rumen-fluid-collection-time-on-itsfermentative-capacity-and-the-stability-of-rumen -conditions-insheep-fed-a-constant-diet/538DDFF6007EA85F481BA13A28916 5D0>. Accessed: Jan. 24, 2014. doi: 10.1017/S1752756200008218.

RYMER, C. et al. In vitro cumulative gas production techniques: History, methodological considerations and challenges. Animal Feed Science and Technology, 2005. v.123-124, p.9-30. Available from: $<$ http://linkinghub.elsevier.com/retrieve/pii/S0377840105001719>. Acessed: Jan. 13, 2014. doi: 10.1016/j.anifeedsci.2005.04.055.

SAS. User's Guide: Statistics Ver 9.0. SAS Inst. Inc.

THEODOROU, M. K. et al. A simple gas production method using a pressure transducer to determine the fermentation kinetics of ruminant feeds. Animal Feed Science and Technology, 1994. v.48, p.185-197. Available from: <https://www.sciencedirect.com/ science/article/pii/0377840194901716?via\%3Dihub>. Accessed: Mar. 12, 2012. doi: 10.1016/0377-8401(94)90171-6.
VAN SOEST, P. J.; ROBERTSON, J. B.; LEWIS, B. A. Methods for dietary fiber, neutral detergent fiber, and nonstarch polysaccharides in relation to animal nutrition. Journal of Dairy Science, 1991. v.74, n.10, p.3583-3597. Available from: <http://www.ncbi. nlm.nih. gov/pubmed/1660498>. Accessed: Mar. 21,2014. doi: 10.3168/jds.S0022-0302(91)78551-2.

VAN SOEST, P. J.; WINE, R. H.; MOORE, L. A. Estimation of the true digestibility of forages by the in vitro digestion of cell walls. Helsinki. Finland: Finish Grassland Association, 1966. p.438-441. Available from: <https://www.cabdirect.org/cabdirect/ abstract/19670700081>. Accessed: Jan. 12, 2014.

WILLIAMS, B. A. Cumulative gas production techniques for forage evaluation. In: GIVENS, D. I. et al. (Ed.). Forage Evaluation in Animal Nutrition. CABI Publishing Wallingford., 2000, p.189-213. Available from: <https://research.wur.nl/en/ publications/cumulative-gas-production-techniques-for-forageevaluation>. Accessed: Jan. 12, 2014.

YANG, W. Factors Affecting Rumen Fermentation Using Batch Culture Technique. In: FAUSTINO JOZALA, A. (Ed.). Fermentation Processes, InTech, 2017, p.77-92. doi: $10.5772 / 64207$ 